
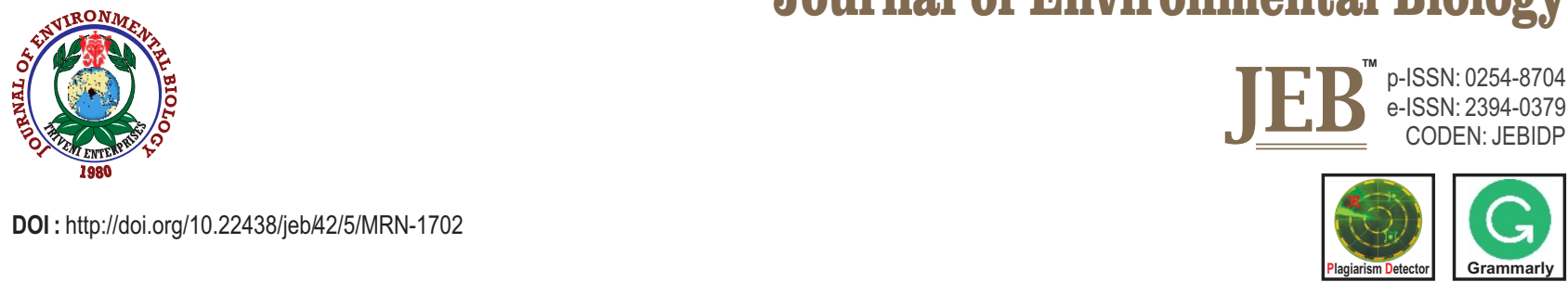

\title{
Sugarcane bagasse biochar: A suitable amendments for inland saline pond water productivity
}

\author{
C. Raul', S. Prakash', S. Lenka ${ }^{3}$ and V.S. Bharti ${ }^{1 *}$ \\ ${ }^{1}$ Aquatic Environment and Health Management Division, ICAR-Central Institute of Fisheries Education, Mumbai-400 061, India \\ ${ }^{2}$ Aquaculture Division, ICAR-Central Institute of Fisheries Education, Mumbai-400 061, India \\ ${ }^{3}$ Environment soil science, ICAR-Indian Institute of Soil Science, Bhopal-462 038, India \\ *Corresponding Author Email : vsbharti@cife.edu.in
}

\begin{tabular}{lll}
\hline Received: 25.09 .2020 & Revised: 05.04.2021 & Accepted: 08.06 .2021 \\
\hline
\end{tabular}

\section{Abstract}

Aim: To ameliorate the inland saline water through biochar for enhancing the pond water productivity and utilize the vast resources of salt affteced land and ground saline water efficiently for aquaculture.

\begin{abstract}
Methodology: A 50 days incubation study was conducted to understand the ameliorating effects of sugarcane bagasse biochar on the inland saline sediment and water. Biochar was applied at the rate of $100 \mathrm{~g}$ and $200 \mathrm{~g}$ in both sediment and water, respectively.
\end{abstract}

Results: Significant ( $\mathrm{P} \leq \mathrm{0.05})$ increase in $\mathrm{pH}$, available- $\mathrm{N}$, potassium, available-Pand decrease in total alkalinity was observed in all the treatments. The primary productivity significantly increased $(P \leq 0.05)$ in all the treatments, and the maximum was observed in $\mathrm{T} 4$ treatment $(0.173$ $\mathrm{mg} \mathrm{m}^{-3}$ ).

Interpretation: The sediment

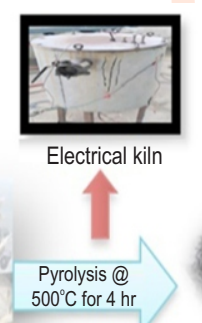

SB waste

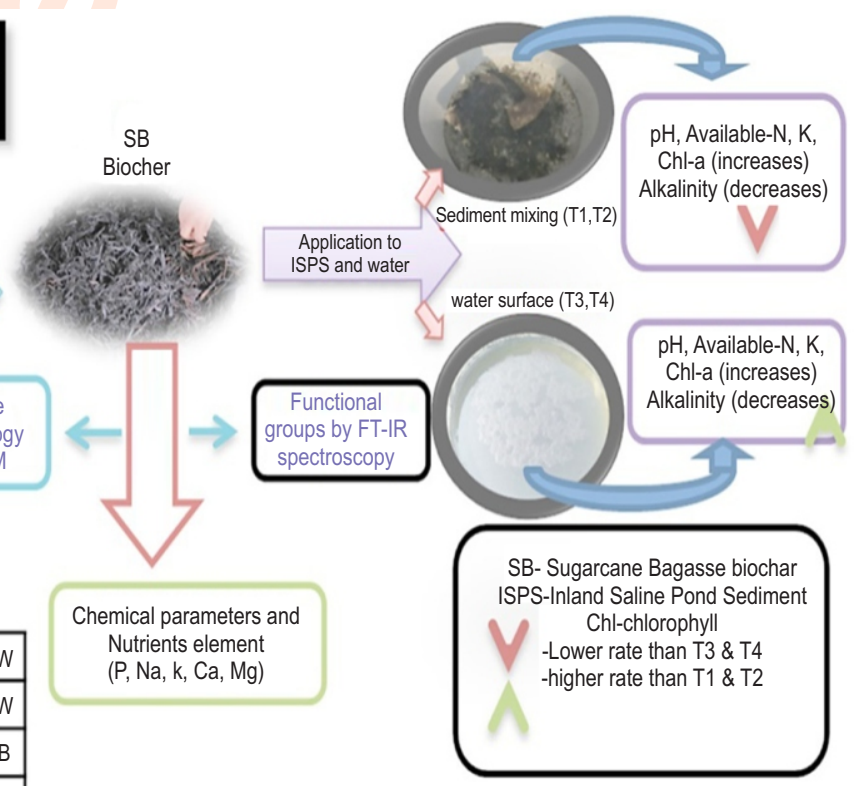
mixing and water application differ in their effect on the primary productivity and physico-chemical properties of inland saline pond water. The study will help in developing protocol for the application of agro-waste-derived biochar in the inland saline pond aquaculture system.

Key words: Biochar, Inland saline, Primary productivity, Salinization, Water quality

How to cite : Raul, C., S. Prakash, S. Lenka and V.S. Bharti: Sugarcane bagasse biochar: A suitable amendments for inland saline pond water productivity. J. Environ. Biol., 42, 1264-1273 (2021). 


\section{Introduction}

Increasing soil salinity is a global issue, and most susceptible areas include semi-arid to arid regions of the world. (Abrol et al., 1988; Singh et al., 2017). Soil salinization occurs through primary and secondary processes (Rengasamy, 2006). Primary soil salinization occurs due to the presence of natural salts in soil (Geene et al., 2016) which comes from the weathering of natural salt rocks during the process of soil formation. In contrast, secondary salinization occurs due to anthropogenic activities (Williams, 2001) such as excessive irrigation of agricultural lands, frequent application of chemical fertilizer, and poor drainage condition of the soil (Brinck and Frost, 2009). Salts precipitate in soil as chlorides and sulfates of sodium, calcium, and magnesium. Water-logging condition (Rao et al., 1991) due to the expansion of canal irrigation and groundwater lifting irrigation through bore well leads to a gradual accumulation of salts on surface soil, which is the principal cause of secondary salinization of agricultural lands in semiarid tropical areas (CSSRI, 2011). Salinization of aquifer also occurs due to irrigation and heavy pumping of groundwater despite the presence of natural ground saline water in underground salt rocks (Foster and Chilton, 2003). Globally salt-affected soil is spread over an area of about 1000 mha (Sandeep et al., 2013) of which salinization due to secondary sources affects over $380 \mathrm{mha}$ of land in over 20 countries (Lambers, 2003). India has an estimated salt-affected area of 6.73 mha of which 1.93 mha areas are laden with ground saline water (Pathak et al., 2013; Lakra et al., 2014).

This necessitates the need for the development of appropriate technology to ensure the alternate use of these unused resources. Aquaculture offers an opportunity for economical utilization of these land and water resources through fish and shrimp farming (Partridge and Lymbery, 2008). Farmers in India and other countries are utilizing the ground inland saline water for the culture of salt-tolerant fish and shellfish species by pumping out groundwater into man-made earthen inland saline pond ecosystem (Allan et al., 2009; Talukdar et al., 2020). For successful aquaculture practice, the natural pond productivity in terms of primary producer is essential as it serves as natural food for fishes and other members of the pond community structure such as zooplankton (Niraj and Singh, 2014). The primary productivity of the pond ecosystem depends upon the nutrient content of the system (Aayyappan, 2011). The nature and properties of pond sediment and water quality are significant factors that govern the primary productivity of pond ecosystem.

The artificially formed inland saline pond (ISP) ecosystem has lower primary productivity and plankton diversity (Awal and Christie, 2015), which may be attributed to the lower/imbalanced level of primary nutrients like nitrogen, phosphorous and, potassium (Aayyappan, 2011). The ground inland saline water varies from natural seawater in terms of nutrients and elemental composition (Soaud et al., 2003). Ground inland saline water, in general, has a lower potassium level, variable calcium and magnesium ratio, and deficiency of trace elements (Sharma and
Tyagi, 2004). Apart from that, the sediment of inland saline pond has loose soil aggregates due to comparatively lower soil organic carbon content. It also has a high seepage rate and low CEC, leading to continuous leaching of nutrients from the system (Stumm and Morgan, 1996). A high concentration of sodium deposits in saline soil in the form of sodium carbonate/ bicarbonate (Handa, 1975; Chhabra, 1996) leads to high fluctuation in pH and alkalinity of inland saline pond water (ISPW). In this regard, biochar may provide a win-win scenario for enhancing the properties of inland saline soil and water system (Laird et al., 2008). Soil fertility management through biochar application was first reported from terra preta in the Amazon region of SouthAmerica (Lehmann et al., 2003).

Recent studies have demonstrated that biochar addition is effective in improving the physical, chemical, and biological properties of salt-affected soils (Lashari et al., 2013). Biochar is a fine-grained, carbon-rich, porous product obtained from agrowaste, which has been subjected to thermochemical conversion process (pyrolysis) at a very high temperature $\left(350\right.$ to $\left.600^{\circ} \mathrm{C}\right)$ in an environment with little or in absence of oxygen (Amonette and Joseph, 2009). It can be produced from any organic waste like an agricultural crop, industrial, urban, or animal waste (Lehmann and Joseph, 2009). The use of biochar-manure compost on saltstressed cropland has shown a significant decrease in soil pH, salt and sodium content, increase in organic carbon, available phosphorus, and potassium (Lashari et al., 2013), which reduces leaching of nitrate-N to groundwater (Chen et al., 2010) and increases agricultural primary productivity (Uzoma et al., 2011). In the present study, sugarcane bagasse biochar derived through pyrolysis at $500^{\circ} \mathrm{C}$ temperature was applied to ISP sediment and water at different dosages to study the effect on nutrients level, water quality and primary productivity of the aquaculture system.

\section{Materials and Methods}

Biochar preparation: Sugarcane bagasse biochar was prepared in an electric heating kiln. The kiln had a diameter of 45 $\mathrm{cm}$ and a height of $70 \mathrm{~cm}$ with an arrangement of central heating plates. There was a removable perforated steel chamber inside the kiln for holding biomass during pyrolysis. The raw biomass of sugarcane bagasse waste was dried to achieve a moisture level below $15 \%$. The dried bagasse was filled in the biomass holding chamber (Fig. 1a) of the kiln, covered with an air-tight steel plate (Fig.1b), and the gas valve was opened for releasing volatile gases produced during pyrolysis. The kiln was operated for $4 \mathrm{hrs}$ at $500^{\circ} \mathrm{C}$ using the relay method. The coverlid of the kiln was opened when the kiln reached room temperature (Fig.1c). The yield of sugarcane bagasse biochar was 33\% (Fig.1d).

Characterization of biochar: The chemical properties of sugarcane bagasse biochar pyrolyzed at $500^{\circ} \mathrm{C}$ are given in Table 1. The $\mathrm{pH}$ and electrical conductivity (EC) analysis of biochar was done by mixing distilled water with biochar samples $(1 \mathrm{~g}$ of biochar: $20 \mathrm{ml}$ deionized water) and agitated with a reciprocal shaker for $1.5 \mathrm{hr}$ (Rajkovich et al., 2012). The $\mathrm{pH}$ of the 
suspensions were estimated with a $\mathrm{pH}$ electrode, then filtered with Whatman $42 \mathrm{~mm}$ filter paper, and the filtrate was used for EC determination by EC meter. Total elemental analyses was done after diacid digestion of $0.5 \mathrm{~g}$ of biochar. Out of the total content, $10 \mathrm{ml}$ of sample was taken for total phosphorus determination using a spectrophotometer. The remaining sample was used for the estmation of sodium, potassium estimation in flamephotometer and, calcium, magnesium content by EDTA titrimetric method. Cation exchange capacity (CEC) of biochar was quantified according to the modified method of Song and Guo (2012). Ash content of the biochar was estimated by gravimetric method (Novak et al., 2009). Biochar was transferred into a muffle furnace and combusted at $700^{\circ} \mathrm{C}$ for $6 \mathrm{hrs}$. Functional groups of biochar (Fig. 2) were identified after spectrophotometric analyses in the infrared region, with Fourier transform infrared (FT-IR) spectroscopy (SHIMADZU, FTIR 4100). The total carbon and nitrogen of sugarcane bagasse biochar were analyzed with a CHNS elemental analyzer (Carlo-Erba NA-1500).

Sediment parameters: The initial and final sediment samples were collected after 50 days of incubation study for the analysis of CEC, water holding capacity (WHC), and organic carbon (OC). The CEC of sediment was measured by the ammonium acetate method (Devis and Freities, 1970). The sediment was treated with $1 \mathrm{~N}$ ammonium acetate at $\mathrm{pH} 7.0$ to saturate the colloidal complex, and the excess salt was removed with methanol $(60 \%)$. Ammonium ion was then displaced with potassium by titrating $10 \% \mathrm{KCl}$ at $\mathrm{pH} 2.5$, and finally, the ammonium ion was measured by Kjeldahl distillation. The WHC of sediment was determined by the standard protocols of ASTM (2008). The organic carbon of sediment was estimated by the method of Walkley and Black (1934).

Experimental set-up and water quality parameters: $A 50$ days experiment was conducted to assess the effect of sugarcane bagasse biochar on primary productivity and water quality parameters of inland saline pond water at the Central Institute of Fisheries Education, Rohtak center, Haryana, India. The sugarcane bagasse biochar was mixed @ $100 \mathrm{~g}$ (T1) and $200 \mathrm{~g}$ (T2) with dry sediment $(20 \mathrm{~kg})$ collected from the inland saline shrimp culture pond. Sediment mixed with biochar was laid as a $10 \mathrm{~cm}$ bed on the bottom of Fiber-reinforced plastic (FRP) tanks (60 cm depth and $90 \mathrm{~cm}$ diameter), and subsequently, inland saline water from an adjacent pond filled with $12 \mathrm{ppt}$ groundwater was pumped to the tanks. In treatments T3 and T4, the sugarcane bagasse biochar was directly applied to the water column at $100 \mathrm{~g}$ (T3) and $200 \mathrm{~g}$ (T4), respectively. The saline groundwater of 12 ppt pumped into a shrimp culture pond was used for the experiment. Samples for water quality parameters and primary productivity were collected at a 10 -day interval.

The water quality parameters like $\mathrm{NH}_{4}^{+}-\mathrm{N}, \mathrm{NO}_{3}^{-}-\mathrm{N}, \mathrm{pH}$, total alkalinity, available- $\mathrm{P}$, calcium, magnesium, potassium, and sodium of ISPW were estimated using the standard methods of APHA (2017). The primary productivity of ISPW was determined by trichromatic method (APHA, 2017). Depending on the trophic status, constant volume of water sample was centrifuged at 1000 $\times \mathrm{g}$ for $20 \mathrm{~min}$. The supernatant was removed and $5 \mathrm{ml}$ of extraction solution dimethylformamide was added to the pellet. The pellet was resuspended in the extraction solution through vortex. After $2 \mathrm{hr}$, it was centrifuged and the absorbence of supernatant was read on a spectrophotometer in the visible wavelength. In this method, the optical density (OD) was read at $664 \mathrm{~nm}$ wavelength to determine chlorophyll- a content. The OD reading at $750 \mathrm{~nm}$ was a correction for turbidity. This reading was subtracted from the OD value at $664 \mathrm{~nm}$ before using them in the equations below because the $\mathrm{OD}$ of the extract at $750 \mathrm{~nm}$ is very sensitive to changes in the acetone-to-water proportions, adhere closely to 90 parts acetone:10 parts water (v/v) formula for pigment extraction. The concentrations of chlorophyll-a in the extract was estimated by the corrected optical densities in the equation, $\mathrm{Ca}=11.85^{*}$ (OD664) - 1.54 * (OD647) -0.08 * (OD630), where $\mathrm{Ca}$ is the concentrations of chlorophyll-a.

After determining the concentration of pigment in the extract, the amount of pigment per unit volume was calculated by the following formula:

$$
\text { Chlorophyll-a }\left(\mathrm{mg} \mathrm{m}^{-3}\right)=\frac{\text { Ca } \times \text { Extract volume }(\mathrm{It})}{\text { Volume of water sample }\left(\mathrm{m}^{3}\right)}
$$

Statistical analysis: All the water quality and primary productivity data were statistically analyzed by One-way ANOVA, and the mean values were compared with Duncan's Multiple Range Test. The SPSS 16 software package was used for data analysis.

\section{Results and Discussion}

Biochar is highly recommended in the degraded system due to its unique properties of high surface area and cation exchange capacity. This is a first report of application of biochar in aquaculture system. It enhances the water holding capacity of the inland saline soil which has high seepage problem. CEC of final Inland saline sediment in all the biochar treatments significantly increased, and there was no change in control (Fig. 3) during the incubation period of 50 days. It was observed that the increase in CEC was highest in T4 (59\%) and lowest in T1 (6.2\%) treatment. The biochemical basis of the rise in CEC of sediment may be attributed to the presence of oxidized functional groups of biochar, which was indicated by high oxygen and carbon ratios on the surface of charred materials following microbial degradation (Liang et al., 2006). FT-IR analysis of bagasse biochar (Fig. 2) also showed the presence of oxidized functional groups $(-C=O$, $\mathrm{C}=\mathrm{O}=\mathrm{C}-$ ), which may contribute to effective $\mathrm{CEC}$ of sediment.

The high surface area, aging, and formation of functional groups $(-\mathrm{COOH})$ due to surface oxidation (Gundale and DeLuca, 2006) of biochar could increase the final CEC of sediment. There was a significant $(P \leq 0.05)$ increase in organic carbon content $(3$, $3.82,3.65$, and 3.78 times) in treatments $\mathrm{T} 1, \mathrm{~T} 2, \mathrm{~T} 3$, and $\mathrm{T} 4$ 


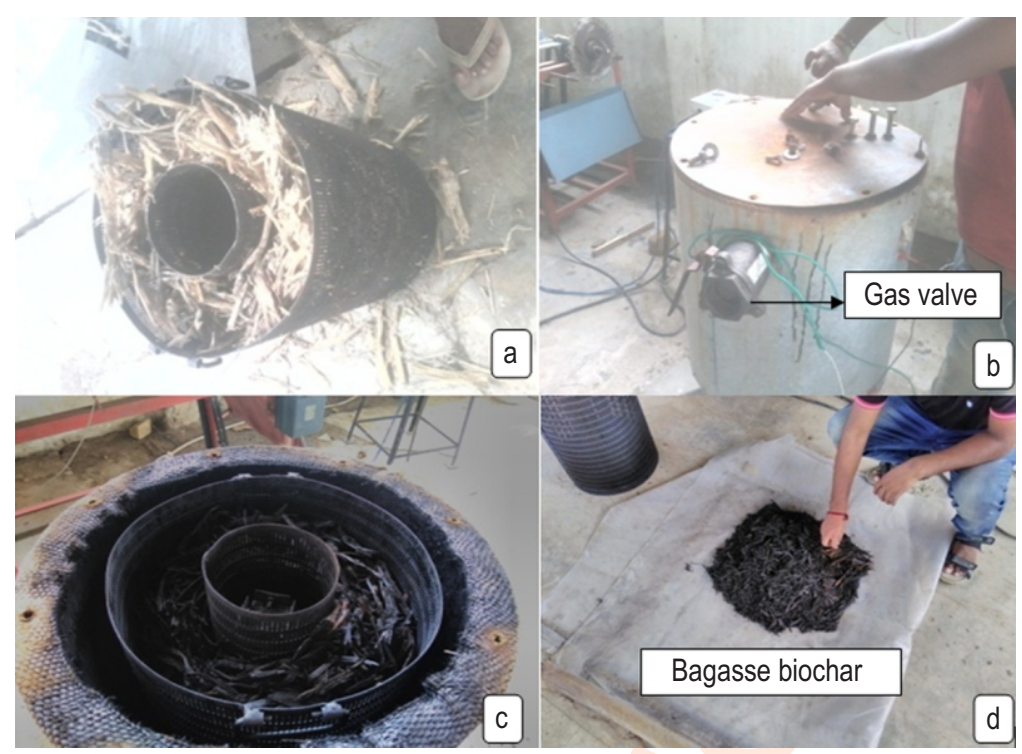

Fig. 1: Sugarcane bagasse biochar production using the electrical heating kiln (a) biomass holding chamber; (b) coverlid of kiln; (c) removal of biochar and (d) bagasse biochar.

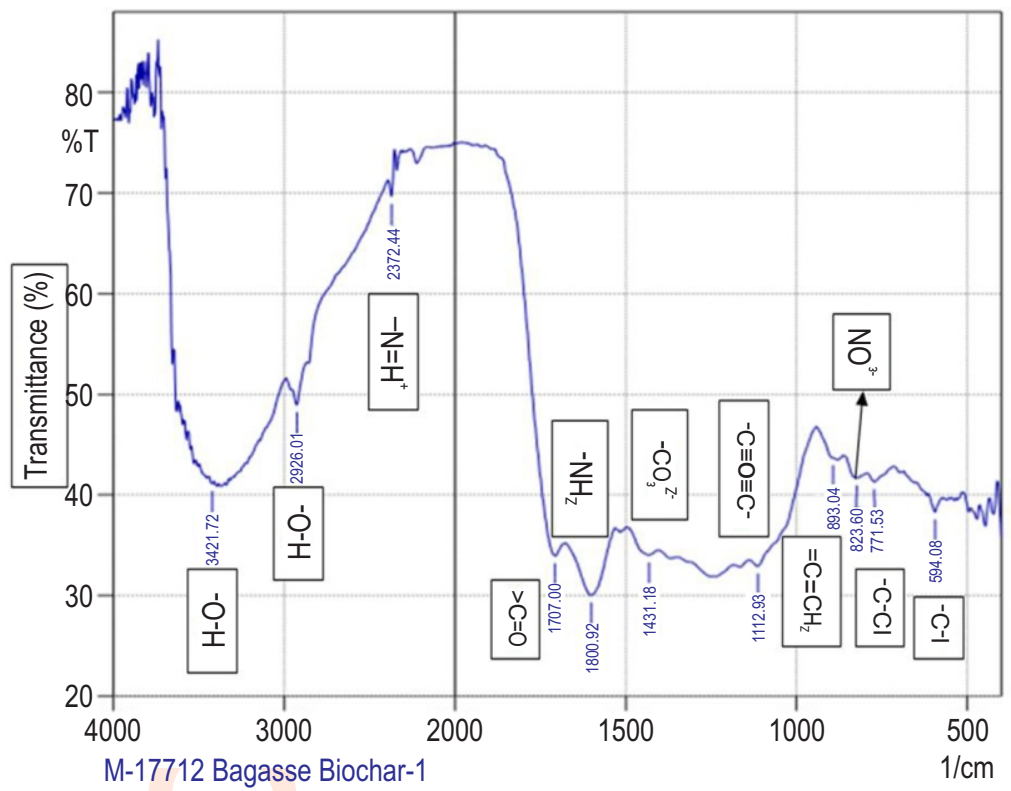

Fig. 2: Molecular absorption in the infrared region with Fourier transforms infrared (FT-IR) spectroscopy of the biochars produced at $500^{\circ} \mathrm{C}$.

treatments of inland saline pond sediment, respectively. However, it was found to reduce in control saline sediment by 1.13 times the initial value (Fig. 3). The increase in organic carbon content in the treatment groups was due to the presence of high labile carbon of sugarcane bagasse biochar (Table 1) (Chan et al., 2008). Organic carbon has three different types of fractions viz., labile carbon, very labile carbon and non labile carbon. In biochar, the formation of non labile carbon percentage increases due to pyrolysis and in the sediment interaction of 60 days incubation the mineralisation is not so fast. As the time increases, the mineralisation process get fasten. So there is no significant difference between treatments. Microbial mineralization of sediment organic carbon may have caused a reduction in the final organic carbon content in control sediment (Bhaduri et al., 2016). 

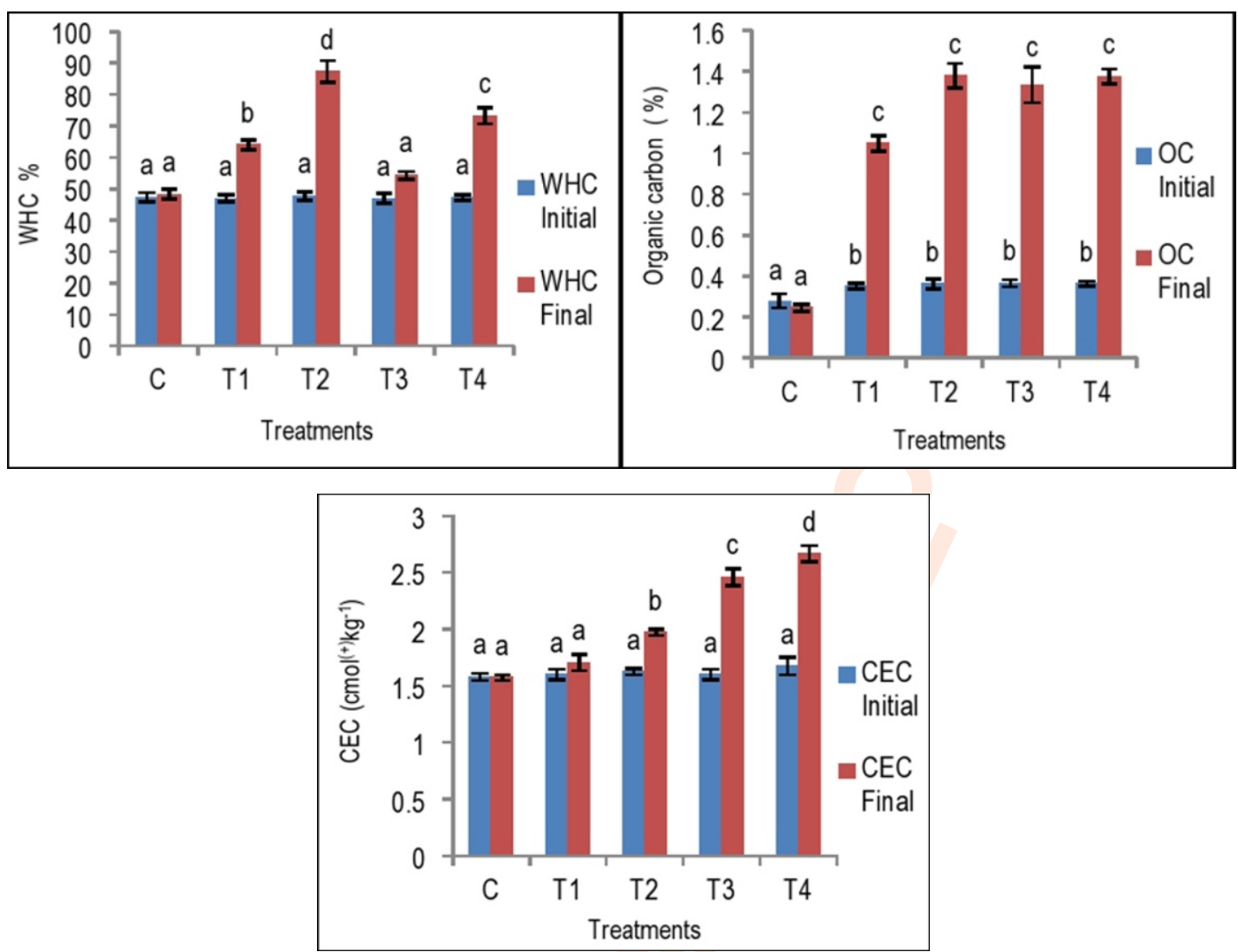

Fig. 3: Sediment quality parameters (WHC, OC, CEC) of initial and final sediment sample.

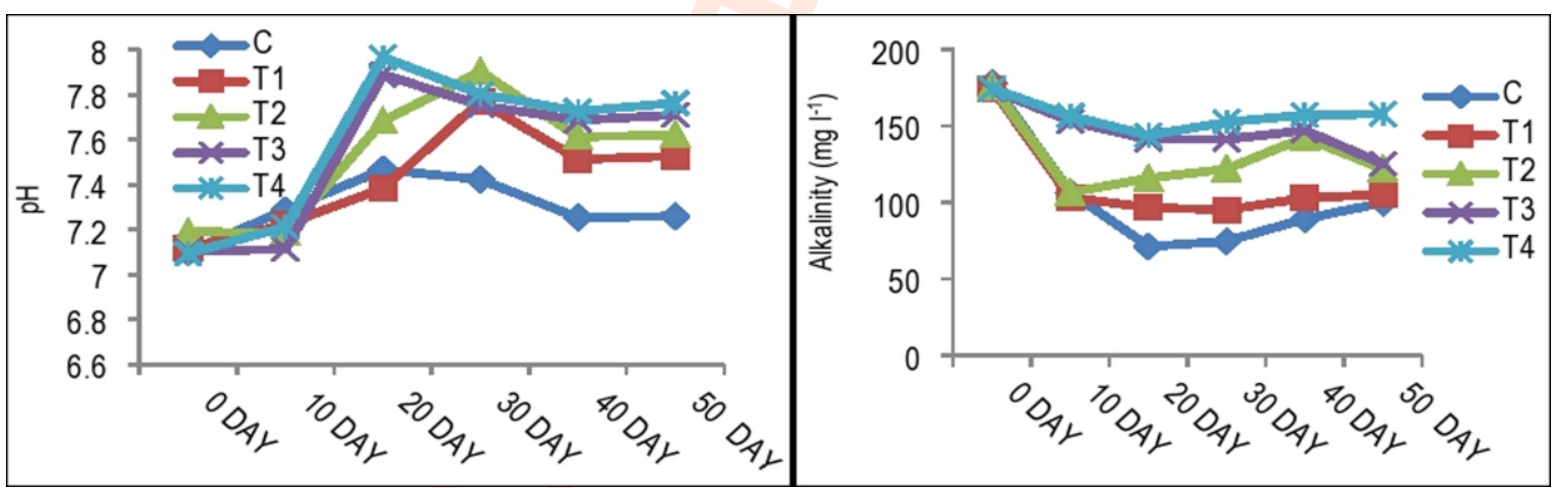

Fig. 4: Chemical parameters ( $\mathrm{pH}$, alkalinity) of inland saline pond water.

There was no change in water holding capacity of control sediment after 50 days of incubation period. In comparison, the water holding capacity of inland saline pond sediment after treatment significantly increased by $1.36,1.8,1.2,1.55$ times in T1, T2, T3, T4 treatments (Fig. 3), respectively. Sugarcane bagasse biochar is a highly porous material and has a high water holding capacity (Table 1), which might have caused an effective increase in water holding capacity of all the treatments at the end of the experiment (Karhu et al., 2011). Sediment aggregation due to the addition of organic carbon from biochar amendment (Atkinson et al., 2010; Liard et al., 2010) may also cause an increase in water holding capacity (Fig. 3). 
C. Raul et al:: Modulating effects of bagasse biochar on inland saline ecosystem

1269
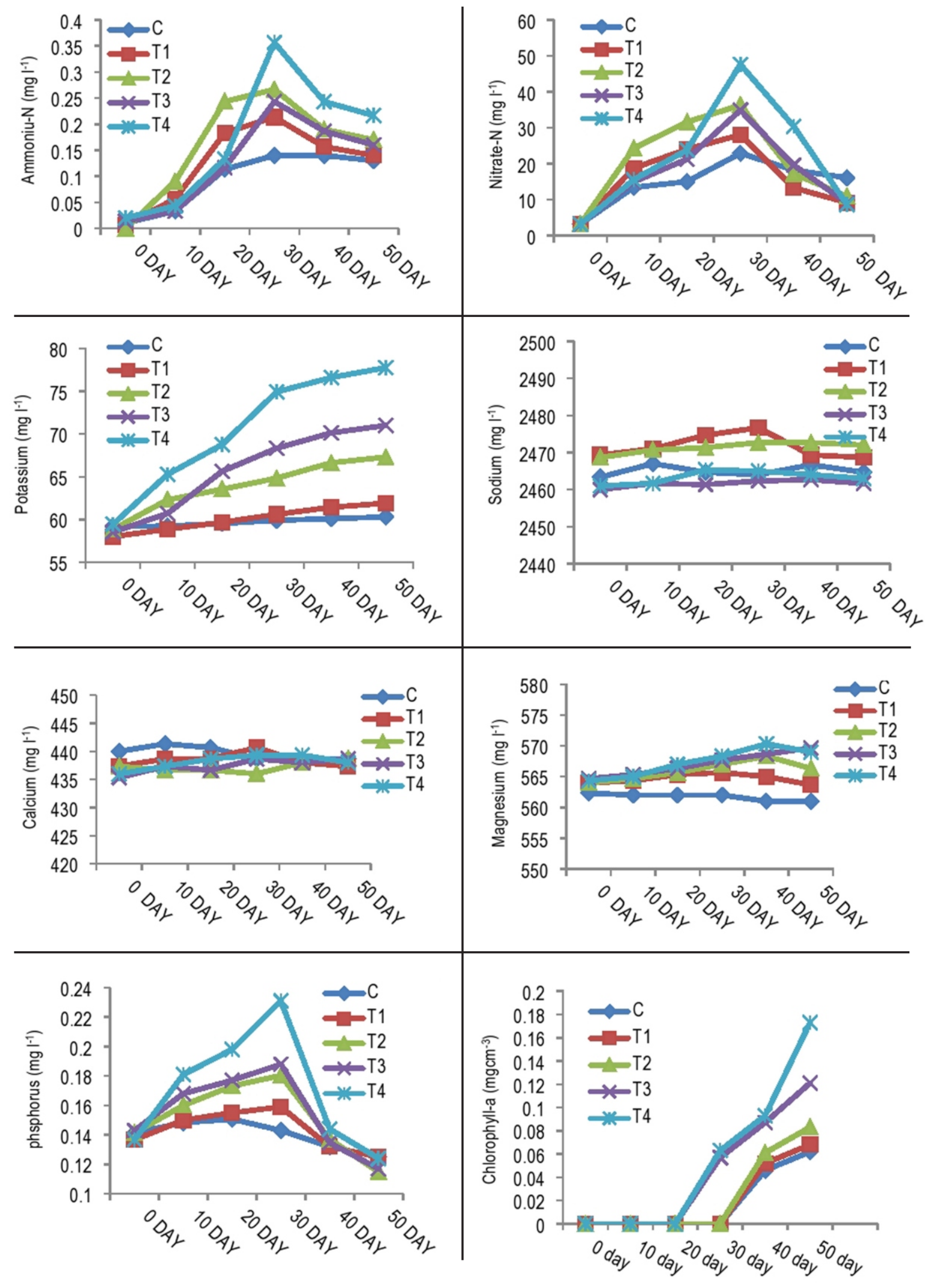

Fig. 5: Nutrient parameters and primary productivity of inland saline pond water.

- Journal of Environmental Biology, September 2021 • 
Table 1: Chemical properties of sugarcane bagasse biochar pyrolyzed at $500^{\circ} \mathrm{C}$.

\begin{tabular}{ll}
\hline Chemical properties & Values \\
\hline pH & $7.1 \pm 0.5$ \\
EC $\left(\mathrm{dS} \mathrm{m}^{-1}\right)$ & $0.62 \pm 0.06$ \\
Ash $(\%)$ & $7.89 \pm 0.8$ \\
Available Nitrogen $(\%)$ & $0.24 \pm 0.02$ \\
Total Carbon $(\%)$ & $56.6 \pm 2.1$ \\
CEC $\left.\left(\mathrm{cmol}^{-1}\right) \mathrm{kg}^{-1}\right)$ & $52.7 \pm 0.5$ \\
Total Phosphorus $\left(\mathrm{g} \mathrm{kg}^{-1}\right)$ & $2.4 \pm 0.06$ \\
Available Phosphorus $\left(\mathrm{g} \mathrm{kg}^{-1}\right)$ & $1.8 \pm 0.09$ \\
Total Potassium $\left(\mathrm{g} \mathrm{kg}^{-1}\right)$ & $24 \pm 0.9$ \\
Available Potassium $\left(\mathrm{g} \mathrm{kg}^{-1}\right)$ & $19.7 \pm 0.8$ \\
Total Sodium $\left(\mathrm{g} \mathrm{kg}^{-1}\right)$ & $0.5 \pm 0.01$ \\
Available Sodium $\left(\mathrm{g} \mathrm{kg}^{-1}\right)$ & $0.3 \pm 0.02$ \\
Total Calcium $\left(\mathrm{g} \mathrm{kg}^{-1}\right)$ & $6 \pm 0.07$ \\
Available Calcium $\left(\mathrm{g} \mathrm{kg}^{-1}\right)$ & $4.4 \pm 0.08$ \\
Total Magnesium $\left(\mathrm{g} \mathrm{kg}^{-1}\right)$ & $5.1 \pm 0.04$ \\
Available Magnesium $\left(\mathrm{g} \mathrm{kg}^{-1}\right)$ & $3.8 \pm 0.2$ \\
\hline
\end{tabular}

There was a significant $(P \leq 0.05)$ drop in total alkalinity from 178 to $100 \mathrm{mg} \mathrm{g}^{-1}$ in control, 174 to $105 \mathrm{mg} \mathrm{l}^{-1}$ in T1 and, 176 to $125 \mathrm{mg} \mathrm{l}^{-1}$ in T2 treatments (Fig. 4) at the end of the experiment. The alkalinity decreased by $63 \mathrm{mg} \mathrm{l}^{-1}$ in T3 and $16 \mathrm{mg} \mathrm{I}^{-1}$ in T4. A significant increase in water pH (Fig. 5) was observed in all the treatments and control until $20^{\text {th }}$ day. However, after 20 days, $\mathrm{pH}$ decreased in both treated and control groups, but the value remained higher than the initial value. The $\mathrm{pH}$ increased by 0.27 , $0.41,0.31,0.61$ and 0.67 in control, T1, T2, T3, T4 groups at the end of the experiment, respectively.

The presence of $\mathrm{Na}_{2} \mathrm{CO}_{3}$ (deposits in surface soil due to high evaporation in arid and semiarid climate) in saline soil may be the primary reason for rise in $\mathrm{pH}$ level in inland saline water (Handa, 1975; Chhabra, 1996). When dry saline sediment comes in contact with water, sodium carbonate $\left(\mathrm{Na}_{2} \mathrm{CO}_{3}\right)$ hydrolyzes to form alkaline sodium hydroxide $(\mathrm{NaOH})$ and unstable, weak carbonic acid $\left(\mathrm{H}_{2} \mathrm{CO}_{3}\right)$. This increase in alkaline hydroxide ions from sodium hydroxide causes a significant increase in the $\mathrm{pH}$ of water. The volatile carbonic acid formed dissociates into carbon dioxide and water, neutralizing the carbonate alkalinity of water. Reduction in total alkalinity in treatments was found to be less as compared to control. This may partly be explained by the possible contribution of carbonate ions in treatments by sugarcane bagasse biochar, which is highly alkaline (Fidel et al., 2017;
Parvesh et al., 2017). The concentration of inorganic nutrients such as ammonium ion $\left(\mathrm{NH}_{4}^{+}-\mathrm{N}\right)$ and nitrate ion $\left(\mathrm{NO}_{3}^{-}-\mathrm{N}\right)$ increased. The highest content was obtained in T4 treatment $\left(0.02\right.$ to $\left.0.35 \mathrm{mg} \mathrm{I}^{-1}\right)$, while the lowest content was found in control ( 0.01 to $0.14 \mathrm{mg} \mathrm{l}^{-1}$ ) (Fig. 5). This increase in $\mathrm{NH}_{4}^{+}-\mathrm{N}^{-} \mathrm{NO}_{3}{ }^{-} \mathrm{N}$ in the water column was due to the decomposition of labile organic carbon (Wang et al., 2016) of sugarcane bagasse biochar (Table 1). Sugarcane bagasse biochar application can improve nutrient status, mainly available nitrogen, in saline soil solution through its impact on the abundance and activities of bacteria that enhances nutrient transformation and, hence, the availability of nutrients (Bhaduri et al., 2016). Sugarcane bagasse biochar is ae rich source of available nitrogen (Table 1) in the form of $\mathrm{NO}_{3}-\mathrm{N}$ (Denyes et al., 2014), which was also identified from the FT-IR analysis of bagasse biochar (Fig. 2). This nitrate availability from bagasse biochar may cause a significant increase in $\mathrm{NO}_{3}-\mathrm{N}$ concentration in the water column of $\mathrm{T} 3$ and $\mathrm{T} 4$ treatments.

There was a significant increase in potassium concentration in the water column in all the treatments, but no change was found in the control (Fig. 5). It was observed that the highest increase in potassium concentration (30.8\%) was found in T4 treatment, while the lowest increase $(2 \%)$ was found in control at the end of the experiment. The $\mathrm{T} 1, \mathrm{~T} 2, \mathrm{~T} 3$ treatments showed a $6.7 \%, 14.4 \%$ and $21 \%$ increase in potassium content as compared to the initial value. Potassium is a key nutrient element for primary producers (Wakeel, 2013). Its availability significantly decreases in soil-water solution due to high concentration of sodium, in inland saline soil (Cakmak, 2005). Bagasse biochar having high CEC (Table 1) and available potassium (Table 1) facilitates the increase of potassium in T4, $\mathrm{T3}$ than T2, T1 treatments. There was no significant changes in calcium and magnesium (Fig. 5) concentration of inland saline water in all treatments and control as available calcium and magnesium of sugarcane bagasse biochar (Table 1) are less in comparison to the initial level of ISPW. There was no significant change in sodium concentration (Fig. 5) in both treatments and control. The sugarcane bagasse biochar has a very less amount of available sodium (Table 1), and initial inland saline water had a high level of sodium concentration $\left(2450 \mathrm{mgl}^{-1}\right)$.

The lower amount of sodium in biochar may not significantly change the sodium level in the water. There was a significant $(P \leq 0.05)$ increase in available-P $\left(P_{4}^{-3}\right)$ of ISPW in all treatments than control until $30^{\text {th }}$ day of experiment and then decreased till 50th day (Fig. 5). Among all the treatments, T4 showed the highest increase in available phosphorus (69.8\%),

Table 2: Pearson's co-rrelation coefficient between Chlorophyll-a concentration and water quality parameters.

\begin{tabular}{|c|c|c|c|c|c|c|}
\hline Parameter & $\mathrm{pH}$ & Alkalinity $\left(\mathrm{mg} \mathrm{l}^{-1}\right)$ & $\mathrm{NH}_{4}^{+}=\mathrm{N}\left(\mathrm{mg} \mathrm{l}^{-1}\right)$ & $\mathrm{NO}_{3}-\mathrm{N}\left(\mathrm{mg} \mathrm{l}^{-1}\right)$ & $\mathrm{PO}_{4}^{3 \cdot}\left(\mathrm{mg} \mathrm{l}^{-1}\right)$ & Potassium $\left(\mathrm{mg} \mathrm{l}^{-1}\right)$ \\
\hline Chlorophyll-a $\left(\mathrm{m} \mathrm{gm}^{-3}\right)$ & 0.812 & $0.960^{\star *}$ & 0.582 & 0.655 & $0.824^{*}$ & $0.959^{*}$ \\
\hline
\end{tabular}

The * and ${ }^{* *}$ indicate correlation coefficients at 0.05 and 0.01 significant levels, respectively. 
while control showed the lowest $(4.9 \%)$. The T1, T2, T3 treatments showed a $16 \%, 22 \%, 31.9 \%$ increase in available phosphorous. Sugarcane bagasse-derived biochar had higher available-P than inland saline water (Table 1), which caused more availability of phosphorus to the water column in T4 and T3 treatments than $\mathrm{T} 1$ and $\mathrm{T} 2$. Post $30^{\text {th }}$ day of the experiment, there was a decreasing trend in phosphorous content of water column due to its utilization by the primary producer for biomass production. The primary productivity in ISPW was estimated by measuring the chlorophyll-a concentration in the system. The nutrient status of water influences the primary productivity of water.

The initial chlorophyll-a concentration in inland saline pond water was zero, and no significant change was observed in the first two weeks (Fig. 5). However, after $20^{\text {th }}$ day, the primary productivity appeared in T3 and T4 treatments, which could be due to the increase in water nutrient level (available nitrogen, phosphorus, potassium). After that, an increasing trend in primary productivity was observed in all treatments and control tanks. The chlorophyll-a concentration of control, T1, T2, T3 and T4 treatments at the end of 50 days of incubation period was 0.042 , $0.068,0.083,0.121$ and $0.173 \mathrm{mg} \mathrm{m}^{-3}$, respectively. The chlorophyll-a concentration showed a significant positive correlation with $\mathrm{pH}$, alkalinity, ammonium ion, nitrate- $\mathrm{N}$, and available-P (Table 2). The inland saline pond sediment is very fine-textured (sand $45 \%$, silt $34 \%$, clay $20.67 \%$ ) and forms loose soil aggregates (Raul et al., 2018). The addition of pond water to dried sediment causes suspension of sediment forming flocculates on the water surface (Quirk, 2001), which may hinder the penetration of sunlight for primary producers.

The instability in water parameters (alkalinity, pH, TSS) and less number of phytoplankton may delay the reappearance of primary productivity. From $20^{\text {th }}$ day onwards, there was an increase in primary nutrients in the water column, a decrease in turbidity, which caused an increase in primary production till the end of the experiment (Fig. 5). A significant increase in the nutrient level of water may be due to increase in water holding capacity and organic carbon of sediment, which may decrease leaching of nutrients by forming good sediment aggregates. A significant increase in CEC provides better exchange of nutrients from sediment to the water column. As the biomass of primary producer increases, it decreases $\mathrm{NH}_{4}^{+}, \mathrm{NO}_{3}^{-}, \mathrm{PO}_{4}{ }^{3-}$ contents in the water (Fig. 5). It is reported that the biochar amendment increases plant (maize, radish, acacia) growth in the agriculture field of normal and saline soil (Uzoma et al., 2011; Drake et al., 2016). Aquatic ecosystem productivity is different from the agriculture ecosystem, but biochar, an agro-waste, has proved to be pivotal in improving water quality parameters and nutrient availability through a significant increase in primary productivity of an aquatic ecosystem.

From the above study it can be concluded that application of biochar in sediment as well as in water is effective in improving water quality and enhancing primary productivity. Furthermore, the study also illustrates that a lower dose of biochar application to water is better than the higher dose of application in sediment. Biochar application in ISPW can further enrich the systemm with potassium, which are deficient in the system, and is crucial for the osmoregulation of fishes and crustaceans reared in ISPW. Such innovative studies may offer ways to enhance the productivity of degraded soil and waterthrough agricultural crop waste biochar, thereby encouraging their utilization for aquaculture purposes and utilization of vast degraded land resources and saline ground water for aquaculture.

\section{Acknowledgments}

We are thankful to the Director of the ICAR-Central Institute of Fisheries Education, Mumbai, India for providing wellequipped laboratories for the research work and the Indian Council ofAgricultural Research, New Delhi for financial support.

\section{Add-on Information}

Authors' contribution: C. Raul: Overall research and manuscript writing; S. Prakash: Help in experimental plan and execution and manuscript correction; $\mathbf{S}$. Lenka: Help in sample data analysis and manuscript correction; V.S. Bharti: Research conceptualization, overall guidance, manuscript preparation and correction.

Research Content: The research content is original has not been published any where

\section{Ethical approval : Not applicable}

Conflict of interest :The author declares that there is no conflict of interest

\section{Data from other sources: Not applicable}

Consent to publish : All the authors agree to publish the paper in Journal of Environmental Biology.

\section{References}

Abrol, A.P and D.R. Bhumbla: Saline and alkali soils in India- their occurrence and management. FAO World Soil Resources Rep., 41, 42-51 (1971)

Allan, G.L., H. Heasman and S. Bennison: Development of industrialscale inland saline aquaculture: Coordination and communication of R\&D in Australia, NSW Department of Primary Industries -Fisheries Final Report Series No. 100. ISSN 1449-9967 (2009).

Amaral, M.N.B.: Comissao IX-poluiçao dos solos equalidade do ambiente: metaispesadosemalgunsfertilizantes e corretivos. Rev. Bras. doCiencias do Solo., 16, 271-276 (1992).

Amonette, J and S. Joseph: Characteristics of biochar: Micro-chemical properties. In: Biochar for Environmental Management. $1^{\text {st }}$ Edn., Science and Technology, Earth Scan, London, 20 pages (2009).

Amonette, J. and S. Joseph: Characteristics of biochar: Micro-chemical properties. In: Biochar for Environmental Management: Science and Technology. (Eds.: J. Lehmann and S. Joseph) Earth Scan, London, pp. 33-52 (2009).

APHA: Standard Methods for the Examination of Water and Wastewater. 
$22^{\text {nd }}$ Edn., APHA, AWWA, WPCF, Washington DC, USA (2018).

ASTM, Method D 2216-05. Standard Test Method for Laboratory Determination of Soil and Rock. Annual Book of ASTM Standards. Construction. Section 4. Soil and rock (I), Vol. 04.08. ASTM, West Conshohocken, PA(2019).

Atkinson, C.J., J.D Fitzgerald and N.A. Hipps: Potential mechanisms for achieving agricultural benefits from biochar application to temperate soils: Areview. Plant Soil., 337, 1-18 (2010).

Awal, S. and A. Christie: Suitability of inland saline ground water for the growth of marine microalgae for industrial purposes. J. Aquac. Mar. Biol., 3, 00063 (2015).

Ayyapan, S.: Handbook of Fisheries and Aquaculture. $2^{\text {nd }}$ Edn., ICAR Publication, New Delhi, India (2011).

Bhaduri, D., A. Saha, D. Desai and H.N Meena: Restoration of carbon and microbial activity in salt-induced soil by application of peanut shell biochar during short-term incubation study. Chemosphere, 148, 86-98 (2016).

Brinck, E. and C. Frost: Evaluation of amendments used to prevent sodification of irrigated fields. Appl. Geochem., 24, 2113-2122 (2009).

Cakmak, I.: The role of potassium in alleviating detrimental effects of abiotic stresses in plants. J. Plant Nutr. Soil Sci., 168, 521-530 (2005).

Chan, K.Y., L. Van Zwieten, I. Meszaros, A. Downie and S. Joseph: Using poultry litter biochars as soil amendments. Aust. J. Soil Res., 46, 437-444 (2008).

Chen, X.P, F.S Zhang, Z.L Cui, F. Li and J.L Li: Optimizing soil nitrogen supply in the root zone to improve maize management. Soil Sci. Soci. America J., 74, 1367-1373 (2010).

Chhabra, R.: Soil Salinity and Water Quality. Oxford and IBH Publication, New Delhi, India (1996).

CSSRI: Annual Report 2010-2011. Central Soil Salinity Research Institute, CSSRI, Karnal, India (2011).

Denyes, M.J., M.A. Parisien, A. Rutter and B.A. Zeeb: Physical, chemical, and biological characterization of six biochars produced for the remediation of contaminated sites. J. Vis. Exp., 93, 52183 (2014).

Devis, J. and F. Freitas: Cation Exchange Capacity, Physical and Chemical Methods of Soil \& Water Analysis. Food and Agriculture Organization of the United Nations, Rome, Italy (1970).

Drake, J.A., T.R Cavagnaro, S.C Cunningham, W.R Jackson and A.F Patti: Does biochar improve the establishment of tree seedlings in saline-sodic soils? Land Degrad. Devel., 27, 52-59 (2016).

Fidel, R.B., D.A Laird, M.L Thompson and M. Lawrinenko: Characterization and quantification of biochar alkalinity. Chemosphere, 167, 367-373 (2017).

Foster, S.S.D. and P. Chilton: Groundwater; the processes and global significance of aquifer degradation. Philos. Trans R Soc. Lond B., 358, 1957-1972 (2003).

Gundale M.J. and T.H. DeLuca: Temperature and source material influence ecological attributes of ponderosa pine and Douglas-fir charcoal. For. Ecol. Manage., 231, 86-93 (2006).

Handa, B.K.: Geochemistry and genesis of fluoride-containing groundwater in India. Groundwater, 13, 278-281 (1975).

Karhu, K., T. Mattila, I. Bergström and K. Regina: Biochar addition to agricultural soil increased $\mathrm{CH}_{4}$ uptake and water holding capacityresults from a short-term pilot field study. Agric. Ecosyst. Environ., 140, 309-313 (2011).

Laird, D.A.: The charcoal vision: A win-win-win scenario for simultaneously producing bioenergy, permanently sequestering carbon, while improving soil and water quality. Agronomy, 100, 178-181 (2008).
Lambers, H.: Dryland salinity: A key environmental issue in Southern Australia, Plant Soil, 257, 5-7 (2003).

Lashari, M. S., Y. Liu, L. Li, W. Pan, J. Fu, G. Pan, J. Zheng, J. Zheng, X. Zhang and X. Yu: Effects of amendment of biochar-manure compost in conjunction with a pyroligneous solution on soil quality and wheat yield of salt-stressed cropland from Central China Great Plain. Field Crop Res., 144, 113-118 (2013).

Lehman, J., D.C. Kern, B. Glaser, and W.I. Wood: Amazonian dark earth: Origin, Properties, Management. Kluwer Academic Publisher, Dordrecht, Boston, pp. 827-833 (2003).

Lehmann, J. and S. Joseph: Biochar for environmental management, Science and Technology. $1^{\text {st }}$ Edn., Earthscan, London (2009).

Liang, B., J. Lehmann, D. Solomon, J. Kinyangi, J. Grossman, B. O'Neill, J.O. Skjemstad, J. Thies, F.J. Luizao, J. Petersen and E.G. Neves: Black carbon increases cation exchange capacity in soils. Soil Sci. Soc. Am. J., 70, 1719-1730 (2006).

Niraj K. and N.P. Singh: Chemical parameters of soil of Turkaulia Lake of North Bihar (India) in relation to its productivity. Int. Res. J. Environ. Sci., 3, 1-4 (2014).

Novak, J.M., W.J. Busscher, D.L. Laird, M. Ahmedna, D.W. Watts and M.A. Niandou: Impact of biochar amendment on fertility of a southeastern coastal plain soil. Soil Sci., 174, 105-112 (2009).

Partridge, G.J. and A.J. Lymbery: The effect of salinity on the requirement for potassium by barramundi (Lates calcarifer) in saline groundwater. Aquaculture, 278, 164-170 (2008).

Pathak, M.S., K.R. Appidi, V. Harikrishna, D.D. Suresh and K.S. Komalsing: Inland saline aquaculture in India: Status and prospectus. Int. J. Pharm. Biol. Sci., 3, 993-1000 (2013).

Pravesh, K.O., V.S. Bharti, A. Vennila, S.P. Shukla, V. Harikrishna, Y. Gladston and R. Aravind: Efficacy of an, integrated system incorporated with Eichhornia crassipes in phytoremediation of calcium from inland saline water. Nat. Environ. Poll. Tech., 16, 687694 (2017).

Quirk, J.: The significance of threshold and turbidity concentrations in relation to sodicity and microstructure. Aust. J. Soil Res., 39, 1185-1218 (2001).

Rajkovich, S., A. Enders, K. Hanley, C. Hyland, A.R. Zimmerman and J. Lehmann: Corn growth and nitrogen nutrition after additions of biochars with varying properties to a temperate soil. Biol. Fertil. Soils., 48, 271-284 (2012).

Rao, K.V.G.K., S.K. Kamra and P.S. Kumbhare: Drainage for reclamation of waterlogged saline lands in irrigation commands. In: Better farming in salt-affected soils (Eds.: K.V.G.K. Rao, S.K. Kamra and

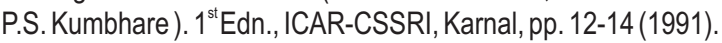

Raul, C., Bharti, V.S., Jaffer, Y.D., Lenka, S. Krishna, G: Sugarcane bagasse biochar: Suitable amendment for inland aquaculture soils. Aquac. Res., 52, 643-654 (2021).

Rengasamy, P.: World salinization with emphasis on Australia. J. Exp. Bot., 57, 1017-1023 (2006).

Sandeep K.P., S.P. Shukla, V. Harikrishna, A.P. Muralidhar A. Vennila, C.S. Purushothaman and R. Ratheesh: Utilization of inland saline water for Spirulina cultivation. J. Water Reuse Desal., 3, 346-356 (2013).

Sharma D.P. and N.K. Tyagi: On-farm management of saline drainage water in arid and semi-arid regions. Irrig. Drain., 53, 87-103 (2004).

Singh, S., I. Jahan, A. Sharma and V.K. Mishra: Inland saline aquaculture -A hope for farmers. Int. J. Glob Sci. Res., 4, 577-593 (2017).

Song, W. and M. Guo: Quality variations of poultry litter biochar generated at different pyrolysis temperatures. J. Anal. Appl. Pyrol., 94, 138-145 (2012).

Stumm, W. and J.J. Morgan: Aquatic Chemistry; Chemical equilibria and rates in natural waters. $3^{\text {rd }}$ Edn., John Wiley and Sons, New York, 1022 pages (1996). 
Talukdar, A., A. D. Deo, N. P. Sahu, P. Sardar, M. Aklakur, S.Prakash and S. Kumar: Effects of dietary protein on growth performance, nutrient utilization, digestive enzymes and physiological status of grey mullet, Mugil cephalus L. fingerlings reared in inland saline water. Aqua. Nutri., 26, 921-935(2020).

Uzoma, K.C., M. Inoue, H. Andry, H. Fujimaki, A. Zahoor and E. Nishihara: Effect of cow manure biochar on maize productivity under sandy soil condition. Soil Use Manag., 27, 205-212 (2011).

Wakeel, A.: Potassium-sodium interactions in soil and plant under saline-sodic conditions. J. Plant Nutr. Soil Sci., 176, 344-354 (2013). Walkley, A. and I.A. Black: An examination of the Degtjareff method for determining soil organic matter, and a proposed modification of the chromic acid titration method. Soil Sci., 37, 29-38 (1934).

Wang, Y. L., Zhang, H., Yang, G. Yan, Z., Xu, C. Chen and D. Zhang: Biochar nutrient availability rather than its water holding capacity governs the growth of both C3 and C4 plants. J. Soil Sedim., 16, 801-810 (2016).

Williams, W.D.: Anthropogenic salinization of inland waters. In: Saline Lakes. Hydrobiologia, 466, 329-337 (2001). 